\title{
ТЕРМИНОЛОГИЈА ИСХРАНЕ У ОБРЕДНОЈ ПРАКСИ ВЕЗАНОЈ ЗА КРСНУ СЛАВУ КОД СРБА У ДУНАВСКОЈ КЛИСУРИ (РУМУНИЈА)
}

\begin{abstract}
У раду ће бити представљена и анализирана терминологија исхране у обредној пракси која је везана за Крсну славу код Срба у Дунавској Клисури (Румунија).Терминолошки корпус је начињен на основу ауторових теренских запиca, сакупљених 2017. године у селима Дивич, Стара Молдава и Белобрешка. Термини који се представљају у раду биће посматрани и у оквиру општег контекста њихове употребе и на тај начин биће указано на значај који имају у обичајно-обредној пракси везаној за Крсну славу код Срба у овом делу Румуније. Циљ рада је, дакле, представљање терминолошке лексике у овом домену и, тиме, њено чување од заборава, као и указивање на функцију ових термина у оквиру самих обреда. Као прилог раду наведено је неколико рецепата славских јела, сакупљених у поменутим селима, а датих у виду транскрипата.
\end{abstract}

Кључне речи: Срби у Румунији, обичајна пракса, Крсна слава, терминологија исхране, рецепти

Ја не купим, ови сви купу колачи. Даду команду тамо у пекару и се праи хлеб, не ја. Господин наш попа кад дође, о тетка Богдана, Ви увек, Ви једини у село што праите, ретко кој још прави. Како изађе је добар, али ја знам да је Светаи, обичај, и тако.

(Белобрешка)

Крсна слава или Светац (Свеца) је један од изузетно значајних идентитетских елемената Срба, па тако и оних који живе у Румунији, и обредна пракса чији су се елементи и радње сачували до данас у готово неизмењеном облику. У оквиру прослављања свеца, заштитника куће и породице, уз бројне радње, учеснике и обредне реквизите, значајно место заузимају и сегменти који се тичу исхране. Тако ћемо се у овом раду бавити терминоло-

\footnotetext{
${ }^{1}$ nina.aksic@ei.sanu.ac.rs

${ }^{2}$ Овај текст је резултат рада на пројекту „Истраживање историје и културе Срба у Румунији”, у организацији Научног центра при Савезу Срба у Румунији (Темишвар), као и рада у Етнографском институту САНУ који финансира Министарство просвете, науке и технолошког развоја РС а на основу Уговора о реализацији и финансирању научноистраживачког рада НИО у 2021. години број: 451-03-9/2021-14/200173.од 05.02.2021.
} 
гијом исхране у оквиру славског обреда и покушаћемо да уз сваки термин представимо и његову функцију.

Основни корпус за рад представљају подаци прикупљени на терену 2017. године, бележени код Срба у три насеља у Дунавској Клисури (Румунија) - у селима Белобрешка, Дивич и Стара Молдава, а на основу наших разговора са шест саговорница.

У раду ћемо прикупљене термине поделити у две групе. У првој групи биће представљена четири основна сегмента која се тичу исхране - славски колач, вино, кољиво (жито) и водица, као и глаголи који означавају обредне радње везане за неки од ова четири појма (сечење, резање, ломљење и др.). У прилог издвајању ових појмова као кључних, централних сведочи и следећи цитат из разговора с једном од саговорница: „Сада ујутру само газда иде у цркву, а остали спремају ручак и после литургије долази свештеник - вино, колач и кољиво" (Белобрешка, Св. Лука).

У другој групи наћи ће се термини, тј. називи обредних јела или неких њихових елемената, као и њихове функције и напомене у којој се прилици употребљавају (посно или мрсно) и на који начин, а и овде ће такође бити наведени глаголи који се везују уз ова обредна јела (кувати, пећи, барити, командовати и др.).

\section{І група славске обредне хране}

Славски колач, или пак само колач, где ,детерминатор (одредба) може да изостане уколико је податак контекстуално јасан” (Радовановић, 2014: 80), представља један од основних елемената овог празника, „али и једног од значајних симбола Сунца, који је остао из прехришћанског времена" (Аксић, 2018: 13).

Према казивањима саговорника из посећених села, за припрему славског колача је пре свега неопходно да су руке чисте, затим да се домаћица прекрсти или изговори молитву, те да почне с прављењем колача: „Се помолим Богу, ставим водицу ту и месим колач" (Дивич, Св. Андреј). Основни састојци за славски колач су брашно, вода (млака, обична) и / или водица (освећена, богојављењска, она од Крстовдана), зејтин, квасаи, шећер и со: „Угрејемо вода, брашно, керма, e, овај, метнем кашику меда и мало водице и замесим" (Белобрешка, зимски Св. Никола); „Маја, млака вода, шећер и брашно. Прави се мало тесто, мали квасац, и кад крене, стави се у други суд, већи, где се дода со и јаје” (Белобрешка, Св. Лука). Поред основних састојака, видимо да су неке домаћице додавале и јаја (ако је мрсна слава), али и мају у колач, ${ }^{3}$ што није чест случај. Када се колач замеси, најчешће се ставља у шерпу да би имао кружни облик и да би могао лепо да нарасте: „И ондак имамо једну шерпу ди само то печем, и ондак одозгор га плетем како оћеш” (Белобрешка, зимски Св. Никола).

\footnotetext{
${ }^{3}$ Маја је сирило, тј. желудачни сок преживара који има функцију згрушавања млека.
} 
Иако многи данас не праве славски колач него га поручују, ипак памте како се то некада радило: „А то га погодимо. Раније два се резало. Праили, па није било пекарнице. То није било, ал жене су праиле. Тепсије биле, има фуруна ту доле, имали смо фуруне и лебац се месио, жене месиле лебац, моја мати обично" (Дивич, Св. Андреј). * Што се тиче терминологије која је везана за прављење колача, пре свега се уочавају именице, тј. називи за намирнице неопходне за мешење колача - вода, брашно, водица (мисли се на освештану воду), мед и керма, ${ }^{4}$ као и називи за помоћна средстава при печењу - тепсија, шерпа, фуруна, пекарница. Значајну улогу у терминологији обредне исхране заузимају и глаголи који се везују уз ову обредну радњу, али пошто „код глаголских етнодијалектизама тек са допуном долазимо до потпуне дефиниције значења" (Милорадовић, 2014: 26), што је важно зато што је реч „о лексици која је, преставши да буде атрибуирана као општа, променила своју улогу" (Милорадовић, 2014: 26-27), овде ћемо уз глаголску реч у заграду ставити и појам (именица у функцији објекта) на који се он односи. Тако се овде срећу следећи глаголи којима се именују неке од обредних радњи: ставити (водицу у тесто за колач), (за)месити, спремати и правити (колач), угрејати (воду), метнути (мед, водицу идр.), пећи (колач), плести (украшавати колач плетеницом) и погодити (наручити колач из пекаре у новије време).

Украшавање славског колача заузима значајн део обредне праксе. Према украсима, сагледава се вичност домаћице, али и њен труд да колач изгледа што лепше: „Обично, правим ја, моја мама тако је, и сунце и свакејаке обичаје, жито, ел шта знам ја, ја ке тако праимо, знате, тако ондак тињимо, знате, ондак увијем, ондак сецкам, праим сунце, праим крст, сваке разне украсе. Праим све од леба” (Белобрешка, зимски Св. Никола); „Са тестом, се праи тесто око наоколо се праи ко кика, посреди се метне то тесто и онда среди се, окопа мало, се метне доле тесто, се праи једна лепа ружа од теста исто, и се метне ту. У тесто се завуче босиљак” (Дивич, Аранђеловдан); „Обичан хлеб, па исплетем једну кику, па ставим около, и одозго знак Исусов” (Белобрешка, Св. Петка); „Како се праи крст, тако крс, и ондак овде се засече - и одовуд, и одовуд, и одвоуд, и на среди се праи ружа, и ту се мете босиљак кад је дође попа, ту се метне босиљак” (Дивич, Св. Андреј); „Руже, крст, и на средини се стави поскур" (Белобрешка, Св. Лука) * Сунщее, жито, крст, кика, знак Исусов, ружа и поскур - све су то симболи који се праве од леба, тј. теста, а како би се добио одређени облик, то тесто се засече или му се средина окопа, да би могла да се метне ружа од теста, а касније и гранчица босиљка.

Након украшавања, колач се пече с посебном пажњом: „Има онда да крене и онда се пече, тако нам рекла једна калугерица из манастира - цео

\footnotetext{
${ }^{4}$ Керма је локални гласовни лик за уобичајеније герма, кулинарски термин, германизам са значењем „квасац”.
} 
сат да се пече лагано, ондак оно изиђе пун овако" (Белобрешка, зимски Св. Никола); „Ето то, и да не буде јако румен или, шта знам ја, изгорен; бринем да се испече јер то представља лице Светитеља, не” (Белобрешка, Св. Петка). * Дакле, колач се пече, а брине се да не буде изгорен, али мора да буде румен и да изиђе пун.

Као што је истакнуто у једном коментару, у неким породицама се након печења у средину колача стављао и босиљак, а онда се колач остављао на послужавнику да преноћи.

Славски колач раније су секли / резали мушкарци / људи из куће, и то на навечерје, или би то чинио свештеник који је долазио да освешта водицу: „Па све по реду, јело све по реду се спрема, колач спремимо, сад ни попа реже. Пре нисмо, резали људи, све док био деда у кућу, а сад сви попу доведемо, и он, и ето, и спремимо колач” (Дивич, Аранђеловдан); „Па резали смо тако ко и попа што ни реже, и се вечера, и се реже колач. Газда и унук. (...) На Велики дан то попа" (Дивич, Аранђеловдан). Данас колач најчешће реже свештеник, и то на сам дан Славе (Велики дан): „Сад ја морам с попом. Они нису ни сваку годину за Свеца кући, не може да дођу, и ондак ја режем сас попом, шта да радим. Јел вичем комшију, сам терала једаред, имамо попу у Живице, што је овде код нас, ал ни се запопио, није ишо сас попом. Ја кажем: Живице, узни ти режи колач, мисим, баба Борице. Он пружи руке, а попа био из Белобрешке, не наш. Каже: не, не, ти режеш твој колач, а он ће реже код њега кући колач, и онај се мануо. Живица после није хтео да реже, после ми се извињаје, каже: Борице, ја нисам крив, попа није дао. Добро, свеједно, режем ја, па шта, није то тако страшно. И тако проведемо и то" (Дивич, Аранђеловдан). * Једна од најважнијих обредних радњи јесте резање колача, а та се радња - како смо забележили - именује искључиво овим глаголом. Пре резања колача, вече пред Славу спремало се јело, а након резања се вечерало. Данас се овај обред резања колача на навечерје углавном изгубио, па се колач поручује из пекаре, а реже се ујутру на Велики дан Славе.

Круну, тј. ружу колача неки су давали стоци на дан Славе: „Ту ружу опкрои попа, како ми, опкрои попа, само мало кад дамо зоб марви, истрошимо ту ружу и дамо марви. Марва поје у зоб. Сутрадан кад прође Свеца, онда се да марви и то се да, то се сачува и се да марви. Ел да се утури свињама ел тако" (Дивич, Аранђеловдан), док су је други чували уз славску свећу и ускршње јаје: „Е то ми стоји. То стоји до идуће године. Та ружа стоји у кућу, јаје од Ускрса, то све стоји. И свећа је иза иконе од Великог дана" (Дивич, Св. Андреј). * Ружа, као сама срж колача, има посебну обредну улогу, па се њој посвећује и посебна пажња. Дакле, њу свештеник - док реже колач - опкрои, па је неко истроши (тј. измрви) стоци или утури свињама, а некоме стоји до идуће године.

Забележили смо и неколико сећања на обичаје прављења три колача годишње, од којих се један мањи реже вече пред Славу, и то га углавном 
режу укућани (мушкарци), а други се реже на дан Славе, тј. на Велики дан, скупа са свештеником: „Се резо колач и увече, се праву колачи. Један за Велики дан и један за навече. Навече, а пре није био попа с(в)е резали они људи, били људи млоги овде резали, а сад њих дође попа, сад. Дође попа у кућу и ни реже колач и ни свешта водицу. То на Велики дан. А то вече јемо ми посно и то не режем колач, само један. Ако режемо сад два, значи режем сад на навече и на Велики дан, ја треба да режем и на Божић. Треба три, тако је обичај. И ондак дође попа, реже, и онда кога, вичеш које оћеш” (Дивич, Св. Андреј); „Па вечера. Пре смо резали и колач. И на навече, а сад не режемо колач. (...) Деца се растурила, ја сама да режем колач, и тако. Попа ни реже на Свеца, на Велики дан, а ми то не режемо. Мањи колач и не режемо” (Дивич, Аранђеловдан).

Када дођу гости, једе се колач за ручак, а најпре се послужи свештеник.

Различити су обичаји везани за остатак колача, па се тако он може дати марви, живини, псу, свињама, док неки сматрају да је колач нешто свето и да га не треба давати животињама него га треба појести: „Па знате, то се не отура ни код живине ни псету се не даје, не, је л то је славно, је благословен, и ондак треба да се поје све, се поје све. Па и не баца се, и он када је добро испечен и добар, то се поје, се поједе све и тако да нема да сутрадан да остане не знам шта млого, и ондак то газда поје, на појутрицу се поје све, да" (Белобрешка, Св. Никола). Чак се и комадићи овога колача чувају током целе године: „Од колача остављамо мало исецкано тако да нам служи за преко целе године, ако је нешто потребно да се узме, да. Јер то освештано, то стоји” (Белобрешка, Света Петка); „Прво се славски колач једе, оставимо то мало што смо рекли за преко целе године. Прво славски колач, да не би остало да се стврдне. Да, прво то да се поједе, па имамо увек по десет и више, и онда се поједе" (Белобрешка, Св. Петка). Такође, могу се давати гостима да у тањиру са другом храном понесу кући: „Па и то дамо на тањир кад гости пођу. Свакем исечемо по једно парче и колача да понесу. У тањиpe, колико тањира толико кришки тога колача, и после оно. Има колача, то је и најслађе, сви се грабу да једу то колаче” (Дивич, Аранђеловдан). * Дакле, колач је нешто што је славно и он је благословен, па неки људи сматрају да не треба да се отура или бациа животињама, већ тако освештан и исецкан остаје за узимање током читаве године, или се његова исечена парчад, тј. кришке, стављају у тањир гостима када одлазе са Славе.

Вино - Вино се „неизоставно (се) употребљава као замена за крв у култу покојника" (СМР, 1998: вино), па оно тако и у неколико сегмената славског обреда има и ову функцију. Оно се, пре свега, оставља да преноћи уз тек направљен славски колач, вече пред Славу: „Купујемо свећу, спремимо колач, ставимо то преко ноћи поред колача једну чашу вина, испред иконе, и свећу, да" (Белобрешка, Св. Петка), а потом се сутрадан вином прелива колач: „То вино, што се прелије колач, стави се преко цвећа” (Белобрешка, 
Св. Лука). Оно је везано и за култ мртвих, те се њиме преливају гробови на навечерје или на трећи дан Славе, у зависности од тога ко у ком периоду дана иде на гробље: „Иде (на гробље) кој иде, ми идемо на навечерје. На навечерје идемо на гробље, носимо све и тад прелијемо мртве све" (Стара Молдава, Петковача). Здравица за госте често се наздрављала чашом вина, а оно је и карактеристичан производ за овај крај, који је богат виноградима. Гости се, такође, веома често служе домаћим вином. * Дакле, вино се стави преко ноћи да одстоји у чаши, а затим се њиме преливају колач и мртви, док се остатак стави преко иявећа.

Кољиво (жито) - Кољиво је важан сегмент обредне исхране, посебно везан за култ мртвих, што се доводи у везу с приношењем „на жртву куване пшенице заштитнику породице и куће" (СМР, 1998: кољиво, панаија). Готово сви саговорници истакли су да се уз славски колач и освећење водице обавезно припрема и кољиво којим се служе гости: „И онда кад дођу, прво служу по једну кашикицу кољива и после остало" (Белобрешка, Св. Петка). У неким се породицама не припрема кољиво за Славу, а изостанак ове врсте послужења карактеристичан је за Аранђеловдан, јер се Арханђел Михаило сматра живим свецем. Ово потврђује и наш саговорник из села Дивич коме је Слава Аранђеловдан. Забележили смо и једно сећање о томе да се кољиво носило на јутро Славе у цркву, скупа са свећом: „Се ишло у цркву, се носила една свећа, се дала, и смо носили едну чашу ко, онај, жито. И то се донесе из цркве, то жито, и ондак се праи једна погача, и ондак колачи" (Стара Молдава, Петковача). * Жито или кољиво се прво носило у чаши у цркву, заједно са свећом, а затим се служило при самом доласку гостију, када су је свако узимао по кашичицу жита.

Освештана водица - Када је у питању освештана водица, мора се напоменути да њена примарна функција није та да чини елемент обредне исхране, али је овде сврставамо у поље обредне исхране јер водица веома често бива један од састојака - свакако посебно важан - славског колача. ${ }^{5}$ Наиме, вече пред Славу (навечерје, навече, уочи Свеца) у кућу је долазио свештеник и освештавао, тј. светио водииу. Овај обичај се код неких породица и данас задржао, док друге освештавају водицу на дан Славе, непосредно пре резања колача: „Па пре радили тако, сада не. Сад дође он, целива све по соби и ондак реже колач. Ондак спремимо све на астал и онда то завршено, готово. А пре требаш да чекамо на навече да иде да свети водицу - тако се звало то" (Дивич, Аранђеловдан). За освештавање водице неопходни су суд са водом, свећа и кита босиљка (која се потом ставља у средину славског колача). У ранијим временима она се употребљавала,

\footnotetext{
${ }^{5}$ Поред стављања у славски колач, освештана водица сипала се и у бунар, или се њоме заливало цвеће: „Кад уочи свеца дође ти чита, то све иде у бунар, то не бацамо. Или неки баца на цвет” (Дивич, Св. Андреј).
} 
а код оних породица које још увек освештавају водицу вече пред Славу употребљава се и данас, као састојак славског колача, који се такође меси вече пред Славу. Поред ове освештане водице, ту су и богојављењска и крстовданска света водица као састојци славског колача, које се користе чак и уместо уља (Белобрешка, Св. Лука): „Славски колач, брашно. Пр(в)ом и пр(в)ом, кад ујутру се дигнемо, лепо се оперем, се прекрстим, имам свету водицу на, од Крстовдан, кад идемо на Благовести да узмемо воду, ја то држим, то сам читала и у књигу из манастира, имам српску, и ставим” (Белобрешка, Свети Никола). * Важно је истаћи да се под термином водица подразумева искључиво освештана водица, па тако „за разлику од деминутивно-хипокористичког значења водица, у коме је значење мотивне речи вода модификовано само са гледишта субјективне оцене, значење 'освећена, света вода' има нови денотат (уп. Јовановић, 2010: 61). Да је реч о лексикализацији значења једног значајног појма из религијске сфере сведочи, на пример, косовско-ресавски говор Крушевца, у коме се поменута семантичка двозначност диференцира уз помоћ акцента: водица у деминутивно-хипокористичком значењу (на првом слогу - Н. А.), а водица у значењу 'освештана вода' (на другом слогу - Н. А.)" (Милорадовић, 2013: 21). ${ }^{6}$ Она се освештава, тј. у локалном идому - свети се (водица) од стране свештеника, а пре тога се све припрема на астал (сто).

\section{II група славске обредне хране}

Када су у питању обредна јела која припадају славском обреду, она се најчешће деле према томе да ли је Слава посна или мрсна, тј. да ли пада у неки од већих постова, или у среду, односно у петак, када су посни дани. Напомињемо да се код Срба у клисурској области изузетно поштују посни дани и веома се води рачуна о томе да ли Слава пада у неки од великих постова. И у једном и у другом случају важно је да ручак буде што свечанији и разноврснији, наравно, у складу са могућностима куће која слави.

Мрсна слава је она која не пада у неки од великих постова или у посне дане (среда и петак). Како за мрсну тако и за посну славу постоје јела која се готово редовно подразумевају и без којих је практично незамисливо да протекне славски ручак. Та јела су - како закључујемо на основу наше грађе - ринфлајш, сарма, супа (супа сос) и печење, живинско месо, итрудла и, данас чешће, ситни колачи: „Па све по реду - супу, сарму, печење. (...) Па како да не. Кажу нису Свеца кад није супа” (Дивич, Аранђеловдан); „А кад је мрсно, се клала живина. Се клала живина, се кувала једна супа, се праила тако супа сос, сад ми увек све то не, и једна сарма. И онда и сарма се праила. Увек сарма. То је купус, и ондак се месо млевено, од свиње што кољемо ми. И метемо прво лука, па метемо после мало то месо, метемо шта треба

\footnotetext{
${ }^{6}$ Више о термину водица видети и у: Милорадовић и Јовановић, 2019.
} 
тунака све и ондак завијемо ту сарму, и то праимо сарму. Прво се да супа, месо, сос, то се прво да на ручак, и за тем се да сарма и за сармом печење. И ондаке штрудла се праи. Сад више ове слатке колаче праву младе, моја праунука, моја, она воли то да праи колачи, и то, пре ми нисмо тако" (Стара Молдава, Петковача). * Дакле, прави се сарма с млевеним месом од свиње која је домаћа и која се закоље, са луком, купусом, па кад се све то мет(н)е тунака, сарма се завије. Поред сарме, незаобилазна на мрсном славском менију била је и суnа coc, чији ће рецепт бити дат у прилогу рада, а поред тога се најчешће клала живина и то се месо служило за славу, јер је скоро свака кућа имала живине. Занимљиво је приметити да се, иако постан, ринфлајш служи искључиво током мрсне славе, вероватно као додатак уз печење, јер се најчешће тако и сервира.

Посна слава, чини се, богатија је јелима, али свакако и захтевнија за припрему. И током посне славе важно место заузима супа, с тим што је овде у питању парадајз-супа, а затим су ту и пребранац или посан пасуль, посна сарма, пиринач, риба, посни ситни колачи, а раније су се правиле и штрудле (Белобрешка, Св. Лука): „Почим то је пос, Божићни пос, ондак јело посно се праи. Парадајз-супа, ел саде многи почели да прае чорбу од рибе, мислим, знате. Али парадајз-супа је била, она је, ондак пребранац и риба се пече, пиринач поред ње, мислим, гарнитура, да. И колачи, пре се праила штрудла, није било слатке колаче. Штрудла са маком, са орасима, са рахатом, то је било пре се правило посно. Посно без јаја или, кој оће, може крофне посне да се праву. Е сад има и праву са маргарином колаче, ове слатке и то, али то је био обичај ондак (...)” (Белобрешка, Св. Никола); „Не, па, на пример, ставимо плитак и дубок тањир, не, кашика, виљушка, нож. Ондак се је... E, и посна сарма се прави на Свети Николу, и посна сарма то е, ондак је најбоља слатка. Е, сад зависи, сад почели неки да је прави са печуркама, али да знате - најбоља, најслађа је она са хлебом, оне коцкице што сечеш коре од хлеба и се суше” (Белобрешка, Св. Никола); „Ми се спремамо. Увече на навече, јер то је посно. То се зна, Свеца се спремамо из пре, праимо посне сарме, посан пасуљ. Пасуљ је главан, а ова кућа имала рибе. Овде су били риболовци и ловци. Риба је била стално свакојака. То није био проблем за рибу, се пржила, се пекла у рерну, се сушила на сунце пре, ја ви кажем од пре како ја знам деду, а сад имамо само пржено, ја је не јем никако. Ја не волим што мирише. Пржим је, све знам, то знам да радим и чорбу да правим, све, све, али не волим да јем. Јем само знаш коју рибу, она што је пуна костију, та је ко пилетина, платика, тако је кажемо, из Дунава" (Дивич, Св. Андреј); „Реко, гле, ја сам јела рибе, више ми се не једе. Пасуљ - то сви једу, кад дођу, сви: еј, дај још пасуља. Се праи црвена супа, а све посно, не сме да биде ту нешто. Ел праим, штрудле купим, они све посно, не мету ништа, и правим црвену супу, и сарму посну правим сас овим, како ми кажемо, не мог ти кажем, има ону, соја. (...) Соја, рендам шаргарепе, кромпир и јабука, метемо 
лебац, али се упржи тај лебац, се испече у рерну да биде ко у песмет. Како ми кажемо - лебац сув. И ондак се исече коцкице, тако мало се исече коцкице и се мете. Они мету зејтина доста. Пиринач.” (Дивич, Ав. Андреј); „Па све по реду - супу, сарму, печење”. И: Је л супа обавезна, јесте: „Па како да не. Кажу: нису Свеца кад није супа” (Дивич, Аранђеловдан); „И лепо је било увек, знате, кад је посно, смо праили рибу, и се праила. (...) Ако је посно, праимо једну парадајиз-супу, једну окешицу, знате. Та ситна, та не пасуљ, и пасуљ се праи, а мој деда увек воло ту окешицу. Она, то се мајка, стара моја баба, она то кувала, деда то воло да удроби леба и то, то је посно било, и риба и окешица, парадајиз-супа, пасуљ, то" (Стара Молдава, Петковача).

* О сложености справљања хране и разноврснијој понуди јела током посне славе сведоче и рецепти за посну сарму, која садржи бројне и неуобичајеније састојке од мрсне сарме: хлеб, тј. лебаи сув, исецкан на коцкице (стављен у рерну да буде ко песмет), ${ }^{7}$ јабуку, кромпир и друго, а данас - и печурке или cojy. Поред разлике у прављењу сарме, тј. у њеним састојцима у старије и новије време, разлике се очитују и када су у питању посластице, али и супа. Наиме, некада је парадајз-чорба или црвена супа била незаобилазан састојак славске трпезе, а данас се уместо ње често прави рибља чорба. Такође, уместо бројних врста штрудли - са маком, са орасима, са рахатом, данас су чешћи ситни колачи са маргарином или посне крофне. Поред ових јела, добили смо и податак да се кувала окешиц̧а, што је зрно налик пасуљу, само је ситније, и у њу се може удробити хлеб. Пасуљ је био, како саговорници кажу, главан, а и риба је била једно од важнијих јела. Она није била, као данас, један од скупљих производа, јер се сва села која смо обишли налазе на Дунаву, па су мушкарци из ових приобалних насеља веома често били и пецароши, тако да су за славу могли донети и добру рибу коју би сами уловили. Риба се затим пекла у рерни, пржила и сушила на сунцу, док се данас углавном само пржи. Једна врста рибе на коју нам је указано, а која има пуно костију и укус налик пилетини, назива се платика. Уз рибу је био обавезан прилог, тј. пиринач или гарнитура.

Позивање на славу је један од важних сегмената читавог славског обреда. На славу се позива на сам дан славе, након што домаћин изађе с јутарње литургије. Током ове обредне радње важну улогу игра ракија. Домаћин или деца позивају госте тако што иду по селу са закићеном флашом и хлепчићима или колачићима, и то од куће до куће: „И ондак око подне, ја знам кад сам била дете, моја мама замедља ракију, знате, замедља ракију, и правиле су неке тако колачиће, а све од брашна, лепо се печеду, лепо колачићи. И ондак нам дали торбе оне од вуне, знате, биле торбице мале и за децу, и ту стави колаче, и ондак не тера да вичемо госте, тако је било пре. Значи, видите,

\footnotetext{
${ }^{7}$ Песмет је позајмљеница из румунског језика, а има неколико значења: 1. презл, презла; 2. двопек; 3. јело од брашна, масти, шећера и јаја.
} 
ставите тај колач и послужи се сас врућом ракијом" (Белобрешка, Св. Никола); „Па ми позивамо, правимо врућу ракију, пре се месио и колач, по један мали колач, па си сваком дао и колач и ракију, си га позвао, позво са ракију. Е сад колач више се не меси, него идемо само са ракијом и позивамо" (Белобрешка, Св. Петка); „Е пре се ишло. Знаш како се праила, један колач овако и пола литре ракије се носило код кога оћеш да вичеш, а сад то све... Неки, неки праву, неки, кад иду да зоведу” (Дивич. Св. Андреј); „Па најмлађи иде сас флашом и... Пре смо носили и колаче. Колач, колико мери имамо да зовемо, фамилије, толико колача у торбу, пре торба се носила на раме. У торбу се ставе колачи, флаша ракије и иде, зове се. Па у подне, пре подне, да дођу на ручак” (Дивич, Аранђеловдан). * Замедљану ракију, врућу, и колачиће који се праве од теста, тј. брашна, и лепо се печеду најчешће су деца носила у вуненим торбицама и с њима су позивала госте, тј. колачићи су давани да деца с њима вичу госте. Данас се овај обичај углавном изобичајио.

Храна и пиће су важан сегмент и поклона који се носи домаћинима. Гости најчешће доносе чоколаде, воће (Белобрешка, Св. Лука) и флашу неког пића, углавном домаћег - вино или ракију: „Може да донесу опет тако једну чоколаду, ил ти ја знам, знате, код нас сад вина, ракије, то има. Може да донесе једну флашу вина ел једну флашу ракије, то није проблем. Никад не дође празан, увек понесе нешто, донесу, да" (Белобрешка, Св. Никола); „Доносе. Неки мали поклончић, вино, шта знам, пиће неко евентуално” (Белобрешка, Св. Петка); „Јел може ако је доно мало вина или тако нешто. Ни се донесивало ништа, ништа" (Дивич, Св. Андреј). Такође, ни гости кући никада не одлазе празних руку, већ им домаћица у тањир стави нешто од славске хране: „Кад испраћамо госте, ондак може да и ставимо, никад не иде се празно. Ставиш неко парче рибе, штрудла, не иде празан кући. За децу, па се да бомбоне, ондак било пре, а саде су чоколаде и има свакојаке феле слаткиша, и се купи, и није то проблем" (Белобрешка, Св. Никола); Пре се давало хране, од свачега по мало, сад не (Белобрешка, Св. Лука); „Даш колаче, помало им даш штрудле, а волу пасуља, и то им метем, и сарме, и рибе и дам, али кад и дам" (Дивич, Св. Андреј). * Дакле, гости углавном доносе дарове, иако смо добили и један одговор да се није донесивало ништа, али им се и стави у тањир при одласку нешто од преостале хране: пасуљ, колачи, штрудла, сарма, риба и др. Ако ко од гостију има децу, њему су се раније давале бомбоне, док се данас чешће дају чоколаде, или пак неки други куповни слаткиш.

Ракија, поред своје улоге у оквиру позивања на славу, има посебну улогу и у домаћиновој (тј. газдиној) славској здравици - њоме се наздравља гостима: „Па он наздрави за здравље, за срећу, напредак. Да буду деца здрава, кућа да иде добро, шта знам ја, даду. С ракијом, да се праи врућа ракија, ондак зима је, Свети Никола је зима, се медља ракија, врућа ракија, после вино и, ко оће сад, и пиво има, и није проблем" (Белобрешка, Св. Никола). 
* Дакле, здравица се најчешће давала са врућом замедљаном ракијом која се праила, а након здравице могло се пити и вино, док се данас често пије и пиво.

О томе да је Крсна слава повезана и с култом мртвих сведоче и обичаји везани за одлазак на гробље (углавном раније, вече пред Славу) и давање задушу трећи дан Славе (рачунајући и вече пред славу), тј. на појутрицу, када се храна дели свим гостима који су били на Слави. Тако се или вече пред Славу носи храна на гробље, или на појутрицу домаћица иде од куће до куће по селу и носи преосталу славску храну: „Се држало одма на навечерје. Се ишло прво на гробље, се прелили мртви, се однео један букет цвећа и то се носило код мртви, и ондак се увече праило навечерје" (Стара Молдава, Петковача); „На гробље идемо пре Славе. Па после други дан се одвоји, да, па од хране (за покојне). Ако је посно - посно, ако је среда или петак, се спрема све посно, ако су други дани, онда обично” (Белобрешка, Св. Петка); „Иде на гроб (вече пред). Пре се ишло, се носило мало орасе, мало бискуице, нешто, и то тако знаш, и после се дође кући.” (Дивич, Св. Андреј); „И ту се јело, се пило, и трећи дан се да задушу, све што остане. Остане штрудле, обично штрудле се праве и крофне, то је посно, то може да се праи посно" (Дивич, Св. Андреј); „И дам кад дам задушу. Напуним велику чинију и носим свима. Свима дам. Шта оћу, метнем свакем једнако колико биду, колико дођу и... Само моја сестрица, она је у Белобрешку у друго село, е њојзи спремим на тај дан и ју дам. А овим носим сутри дан с котарчетом. Метем котарче и метем једну бабицу, метем рибе, метем пасуља, метем и чорбе, и супе, и све, по то се прави више. И ја то све дам. Идем, и на крај села имам једну снају - и њојзи носим, ондак има један што ми помаже да радим - и њему носим. Бабица, па не знаш шта је бабица. То је оно уплетено, бриош румунски се каже. Плетеница једна, али знаш како, оно се уплете овако, тако, од теста. А то ни донесу, командујемо, и сад не праим, не праимо то сад, донесе све готово, то само командујеш, они ти донесу. То се да на тај дан, бабице се дају, то мора да даш, и кад умреду, све се праву за то" (Дивич, Св. Андреј); „Ондак појутрица за мртве се да̂. Ондак опет се купимо сви и праимо, ил је мрсно, мрсно се праи, ил је посно - посно. И праимо те крофне, је ли, праимо нешто, се кади, се кади мртвима. То је појутрица, трећи дан. Иде (Н. А. на гробље) кој иде, ми идемо на навечерје. На навечерје идемо на гробље, носимо све и тад прелијемо мртве, све. На појутрицу дамо кући задушу, не идемо на гробље. А има кој иде на појутрицу, не иде на навечерје. На гробљу ништа не остављамо од хране. Цвеће и свећу палимо, и то, а кући после кад дођемо, ми, кажем, праимо ту вечеру, ако је мрсна - мрсна, ако је посна - посна" (Стара Молдава, Петковача). * Када је у питању одлазак на гробље на навечерје, из исказа наших саговорника дознајемо да су се вином преливали гробови, а од хране су се носили бискуищи (кекс, бисквит) и ораси. Трећи дан, тј. на појутрицу, када се даје задушу, неки су одвајали само слат- 
ко - крофне или штрудле које су посне, па могу дуже да стоје, док су други појутрицу одржавали код куће или су носили готово све од преостале хране, тј. припремали нову храну у случају да је Слава мрсна, а да појутрица пада на постан дан - рибу, пасуљ, чорбу, суnу. Тако су се у напуњену чинију или котарче (корпу) додавале и бабице, производ од теста налик плетеници, или - како смо добили објашњење - бриош на румунском, и све се то давало славским гостима задушу, тј. у част мртвих. Бабице се данас наручују у пекари, тј. командује се да се направе, а ово пециво је и незаобилазан сегмент обредне хране која се везује за сахране.

\section{Закључне напомене}

Сагледавши елементе који сачињавају одбредну исхрану славског обреда код Срба у трима селима румунске Дунавске Клисуре, можемо закључити да неки елементи ове исхране имају посебан значај. То су: славски колач, вино, ракија, водица и кољиво, а на њихов посебан значај указује и бројност обредних радњи које се уз њих везују. Издвајање и анализа елемената обредне исхране, који су ексцерпирани из транскрибованих примера са терена, омогућавају прецизније разумевање целокупног обреда у етнолошком смислу, али дају могућност и лингвистима, а посебно дијалектолозима, да стекну првенствено увид у семантику појединих термина. Наиме, поред именица, у раду су курзивним слогом дати, а понегде и прокоментарисани из етнолошког угла, и глаголи којима се именују одређене обредне радње, као и придеви и прилози важни за опис изгледа издвојених елемената, али и за начин вршења одређене радње током обреда.

Када сагледамо све карактеристике припремања, али и послуживања обредне исхране у оквиру славске обредне праксе, примећујемо да се оне у потпуности уклапају у опште карактеристике обредне исхране код Срба у матици. Обредна храна „се ретко спрема (једном годишње или циклично), одабира се и припрема на за то утврђен начин (коље, пече, ломи, сече), на унапред одређеном месту (кућни праг, поред огњишта, дрвета-записа), а све то обавља одређена особа која се стриктно мора придржавати правила ритуалне чистоће, те са смерношћу и озбиљношћу обавити поверени посао. Ocећај за естетику и своју индивидуалност исказује посебно особа која припрема и креира обредне хлебове и пецива” (Радојичић, 2014: 89).

Поред увида у традиционалне начине припремања и обављања славског обреда, кроз представљене примере са терена може се стећи увид и у промене до којих је дошло у оквиру вршења обреда услед друштвених промена које су се дешавале током протеклих неколико деценија. Модернизација - у смислу електрификације, појаве масовних медија, тј. веће доступности различитих информација, запослења у фабрикама, миграције на 
правцу село-град и друго, довела је и до промена у упражњавању славског обреда. Тако се, на пример, данас купује славски колач у пекари, смањен је број гостију, изобичајено је позивање на славу идењем од куће до куће (што са собом повлачи и изобичајење медљања ракије и прављења посебних колачића), купују се или праве ситни колачи на „модернији” начин, а губе се читаве врсте традиционалних посластица и др. Дакле, како Д. Радојичић истиче, „поред осталог, истраживањима овог типа може се извести и анализа (нових) прехрамбених навика. Данас, притисак професионалних обавеза на радно ангажованог појединца, хроничан мањак слободног времена, урбанизација, маргинализација сеоске средине, њено 'топљење' и свођење на старачка домаћинства, притом радно ангажована женска популација неумитни су чиниоци који видно утичу на трансформацију начина и стила живота у условима континуиране транзиције нашег друштва и транснационалног глобалног капитализма" (Радојичић, 2014: 93).

Анализом обредне исхране, поред праћења некадашњег и садашњег изгледа славског обреда, начина његовог практиковања и значаја исхране у целости, долазимо и до појединости које се тичу повезаности елемената славског обреда са култом мртвих, а које се најјасније очитују кроз обредне радње везане за исхрану - одлазак на гробље и преливање гробова вином, давање хране на појутрицу, задушу и др. Ово се можда може довести у везу са архаичношћу посматраног обреда, посебно ако се има у виду да мање заједнице, оне које су и у мањини на одређеном простору (обично ван матичне територије), боље / више морају чувати своје идентитетске одреднице, па тако и затвореније и дуже опстају одређени обичаји и њихови посебни елементи.

Истрајност у упражњавању славског обреда, са свим елементима обредне исхране, донекле измењеним, али углавном без промењене суштине, сведочи о непрекинутој жељи за опстанком данас већ изумирућих села, некада у већини насељених српским становништвом. Забележени подаци о славској обредној исхрани требало би да нам остану као драгоцено сведочанство о томе да је и на овим просторима славски обред живео и имао изузетан идентитетски значај за Србе. И на самом крају оставили бисмо отворено једно размишљање о томе да ли су за чвршће чување традиције „повољнији” тежи друштвени услови, ако имамо сазнања да је готово неизмењен славски обред опстао и у најтежим условима, као и неки други уосталом, надживевши смањење броја Срба на овом подручју, губљење њиховог утицаја, владавину других народа на датом терену, а затим и званично присвајање ове територије од стране државе Румуније почетком XX века, те опстао и на туђој земљи, док га је „модернизација” (због чијих елемената је дошло до изумирања села и мешовитих бракова у којима је доминантнија традиција већинског становништва) готово сасвим успела да потисне и измени у знатној мери неке његове сегменте. 


\section{Литература}

Аксић, 2018: Н. В. Аксић, Крсна слава као живи елемент традицијске културе Срба у Дунавској клисури (Румунија). Темишвар-Ниш: Исходишта, 4, 9-28.

Ивановић Баришић, 2014: М. Ивановић Баришић, Породична Слава у Срба с посебним освртом на Александровачки крај, у: Нематеријално културно наслеђе и локална средина: резултати савремених мултидисииплинарних истраживања александровачке Жупе и околних области. Александровац: Завичајни музеј Жупе, 43-72.

Ивановић Баришић, 2015: М. Ивановић Баришић, Календарски празници код Срба у Румунији. Ниш: Исходишта, 1, 130-138.

Крстић, 2015: Б. Ђ. Крстић, Народни живот и обичаји Клисураца и Пољадијаца. Посебна издања, Књига 79, Темишвар: Савез Срба у Румунији.

Милорадовић, 2013: С. Милорадовић, Вода и понешто од воде у српским дијалекатским речницима, у: Aquatica: књижевност, култура, Посебна издања 122. Београд: Балканолошки институт САНУ, 11-32.

Милорадовић, 2014: С. Милорадовић, Етнодијалектолошки приступ култури исхране кроз обредну праксу, На материјалу из Ердевика и Парага, у: Обредна пракса - Речима о храни, На материјалу из српских говора Војводине. Нови Сад: Матица српска, 25-47.

Милорадовић и Јовановић, 2019: С. Милорадовић и В. Јовановић, Сложенице са именицом вода у српским народним говорима и српској култури. Београд: Наш језик, књига L, свеска 2, 755-765.

Недељковић, 1990: М. Недељковић, Годишњи обичаји у Срба. Београд: Вук Караџић.

Радовановић, 2014: Д. Радовановић, Хлеб иобредна пракса у Војводини - метнолингвистички оглед, у: Обредна пракса - Речима о храни, На материјалу из српских говора Војводине. Нови Сад: Матица српска, 65-82.

Радојичић, 2014: Д. Радојичић, Аутентични говор хране, у: Обредна пракса - Peчима о храни, На материјалу из српских говора Војводине. Нови Сад: Матица српска, 83-95.

СМ, Словенска митологија енцииклопедијски речник, 2001: (Ред: Толстој М. Светлана и Љубинко Раденковић). Beograd: Zepter book world.

СМР, Српски митолошки речник, Друго допуњено издање, 1998: (Шпиро Кулишић, Петар Ж. Петровић и Никола Пантелић). Београд: Етнографски институт САНУ.

Трубарац Матић, 2018: Ђ. Трубарац Матић, Елементи култа предака у славским обичајима Србаиз клисурских села Румунског Баната (Белобрешка, Дивич, Стара Молдава). Темишвар-Ниш: Исходишта, 4, 373-383.

Ћирковић, 2004: С. Ћирковић, Мек љеб ко сунђур да једеш. Kragujevac: Liceum, $8,85-108$. 


\section{Прилози}

\section{1. Прављење и украшавање славског колача}

„Славски колач, брашно. Пр(в)ом и пр(в)ом, кад ујутру се дигнемо, лепо се оперем, се прекрстим, имам свету водицу на, од Крстовдан, кад идемо на Благовести да узмемо воду, ја то држим, то сам читала и у књигу из манастира, имам српску, и ставим, угрејемо - вода, брашно, керма, е, овај, метнем кашику меда и мало водице, и замесим. И ондак имамо једну шерпу ди само то печем, и ондак одозгор га плетем како оћеш. Обично правим ја, моја мама, тако је, и сунце, и свакејаке обичаје, жито, ел шта знам ја, ја ке тако праимо, знате, тако ондак тињимо, знате, ондак увијем, ондак сецкам, праим сунце, праим крст, сваке разне украсе. Праим све од леба. Има онда да крене и онда се пече, тако нам рекла једна калугерица из манастира - цео сат да се пече лагано, ондак оно изиђе пун овако" (Белобрешка).

\section{2. Рецепт за сос cyny}

„Се мете месо, пилећина, увек живина - пловке, гуске, ћурке, шта имаш, метеш, ту метеш шаргарепy, метеш патроже, метеш изелера, и то се кува све, и обашка бариш неке кромпире. Ова господа више су сад на пире, а ми не, пре ми кромпире барене, и то извадимо из супе и метемо резанце кућевне. Разбијемо јаја, праимо, растињимо обге, исечемо (...). То после кад ври, све оно извадимо, и кад ври, пустимо резанще - то је била супа. И ондак метемо масти и мало брашна, колико, зависи колико оћеш имаш гостију да праиш мало више и праим један сос. И онда кад је то мало се налије се мете парадајз, парадајз овај сос кувани, и то се мете, и то се кој како воли, метемо, имамо шећера у тај сос. И то је било, то је био сос" (Стара Молдава).

\section{3. Рецепт за посну сарму}

„Лепо се сече коре од хлеба, векле како су, да, и ондак исечеш све тако лепо, у четир, лепо, и сушии, и манеш да се осуше, ел саде зими како шпорет гори, ставиш у један и ставиш и мало у рерну кад не гори јака ватра, знате. Кад већ је готов увече, и онда ујутру га манеш тамо у рерну, он се суши. И ондак сарму се, овај, купус, лепо га исечеш, све га спремиш, исечеш, на сарму треба доста лука, доста лука да се динстује, шаргарепа рендана. И ондак има кој ставу по шаку млевеног ораја, знате - ора. И ондак се стави пиринач и се стави тај хлеб, то је место меса, а саде многи узимаду соју, знате, соју и печурке праву, али ја сам праила и са сојом, праила сам и са печуркама, али најбоље је са хлебом, најслађе. Да, са хлебом је јако фино, и кад се доста лука и шаргарепе, се стави уља, то се динстује и јако супер. Кој воли, неки на крај може да стави сос, а неки не, знате. Од парадајза, парадајза, да. Али, мислим, ондак ставиш со, бибер, паприку, у ту смесу све, лепо, и ондак и... да, слатку паприку, да, ирвену. И ондак завијеш сарму, и ставиш, и онда ја, ја ту највише волим. Сарма се кува лагано на ватру. Сар- 
ма се кува лагано, на ватру. Сарма се кува лагано, на шпорет, па сат, сат и по, не треба ако се купус није тврд оно пиринаћ и то, она се скува брзо, али на ватру ти(х)у да ондак да лепо се кува и увек да у кастролу кад ставимо, ставимо један капак преко сарма да се не подигну оне горе, знате. И ондак, она се крчка тако фино, лагано, нема проблема. А да знате да је слатка, само да пробате, зими, зими, ондак кад имате времена" (Белобрешка).

„Соја, рендам шаргарепе и један кромпир и једну јабуку. Да, јер јабука је јако добра у купус, и испраим тако лепе мале сарме, и то сви волу. А шта се мети лебаи, метемо лебац, али се упржи тај лебац, се испече у рерну да биде ко у песмет. Како ми кажемо - лебаи сув. И ондак се исече коцкице, тако мало се исече коцкице и се мете, а ја не волим толико леба, не смем да га јем, имам шећер, ја метем по два, по три. Ја га држим тако и га увијем у то. А не праву сви са сојом. Они мету зејтина доста, то, ја то не смем да јем. Они мету лебац, само с лебом. Пиринач мало, не, ја не метем много, мало, мало. Зависи како ко. Моја мати више мећала, а ја друкше праим" (Дивич).

Nina V. Aksić

\title{
TERMINOLOGY OF NUTRITION IN THE CUSTOMS RELATED TO THE PATRON SAINT OF SERBS IN THE DANUBE GORGE (ROMANIA)
}

\begin{abstract}
Summary
The paper will present and analyze the terminology of nutrition in ritual practice, which was and it is still in use among Serbs in the Danube Gorge (Romania). The terminological corpus will be drawn from the field records of the authors of the paper, which were recorded in 2017 in the villages of Divič, Stara Moldava and Belobreška. The terms presented in the paper will be considered within the general context of use. In that way, the significance they have in the ritual-customary practice of the Patron Saint among Serbs in this part of Romania will be shown. Along with the analysis of the field material, the relevant literature related to this area will be consulted. The aim of the paper would be to present the terminological lexicon and thus keep it from oblivion, as well as to show the useful meaning of these terms in the rituals. As a contribution to the work, several recipes of Saint Patron ritual nutrition, from the mentioned villages will be given in the form of transcripts.
\end{abstract}

Key words: Serbs in Romania, customary practice, terminology of nutrition, recipes. 